DOI: $10.1515 /$ ausfm-2015-0020

\title{
Derek Jarman's Allegories of Spectacle: Inter-Artistic Embodiment
}

\author{
Fátima Chinita \\ Lisbon Polytechnic Institute, Theatre and Film School (Portugal) \\ E-mail: chinita.fatima@gmail.com
}

\begin{abstract}
Derek Jarman was a multifaceted artist whose intermedial versatility reinforces a strong authorial discourse. He constructs an immersive allegorical world of hybrid art where different layers of cinematic, theatrical and painterly materials come together to convey a lyrical form and express a powerful ideological message. In Caravaggio (1986) and Edward II (1991), Jarman approaches two European historical figures from two different but concomitant perspectives. In Caravaggio, through the use of tableaux of abstract meaning and by focusing on the detailing of the models' poses, Jarman re-enacts the allegorical spirit of Caravaggio's paintings through entirely cinematic resources. Edward II was a king, and as a statesman he possessed a certain dose of showmanship. In this film Jarman reconstructs the theatrical basis of Christopher Marlowe's Elizabethan play bringing it up to date in a successfully abstract approach to the musical stage. In this article, I intend to conjoin the practice of allegory in film with certain notions of existential phenomenology as advocated by Vivian Sobchack and Laura U. Marks, in order to address the relationship between the corporeality of the film and the lived bodies of the spectators. In this context, the allegory is a means to convey intradiegetically the sense-ability at play in the cinematic experience, reinforcing the textural and sensual nature of both film and viewer, which, in turn, is also materially enhanced in the film proper, touching the spectator in a supplementary fashion. The two corporealities favour an inter-artistic immersion achieved through coenaesthesia.
\end{abstract}

Keywords: cinematic allegories, inter-artistic spectacle, embodiment, immersive, intermediality, Derek Jarman.

\section{The Language of Allegory}

According to Craig Owens (1980), contemporary art is naturally hybrid, therefore prone to an allegorical dimension, as allegory itself causes the miscegenation of media and stylistic categories: "The allegorical work is synthetic; it crosses aesthetic boundaries" (Owens 1980, 75). In this light, allegory has a meta-textual 
nature and in it different types of artworks, or texts, are intrinsically connected: "In allegorical structure, then, one text is read through another, however fragmentary, intermittent, or chaotic their relationship may be; the paradigm for the allegorical work is thus the palimpsest" (Owens, 69). In post-modernity, allegory has been reinvented as intermediality.

Derek Jarman was a specifically multifaceted artist, whose versatility comes across in his cinematic oeuvre in favour of a very marked authorial discourse, in spite of his defence of collective creation. He was a painter, a theatre and film designer, a writer, a performance artist (committed to the production of happenings), and, of course, a film director. All of this artistic background tightly imbues his films, resulting in an allegorical world where the arts are fused together in a lyrical form that conveys an ideological message.

Never prone to figurative painting, Jarman adopted the allegorical format from very early in his career. As a filmmaker, he chose to ignore the storytelling tradition of the commercial cinema. Indeed, theorists agree that linear narrative was not his forte: "Where there is narrative it is often temporally disjointed and sophisticated, combining several phases, viewpoints and character sets" (Wollen 1996, 15). In other words, Jarman makes a lyrical use of narrative contents, ignoring the story in favour of the storytelling, thus indirectly exposing the technique of creative production. In his works, narrative always takes second place to the visual art and the theatrical design with the consequence of a notorious degree of abstraction (Watson 1996, 34). Jarman had a problem with creating narrative dialogue, which is why he either resorted to previously written material (such as Christopher Marlowe's play on Edward II) or substituted it for interior monologues whenever possible. In the latter case, the "loosely associative and poetic patterns of thought" (Watson 1996, 37) reinforce the allegorical dimension of his films. ${ }^{1}$

In spite of their allegorical nature, Jarman's films are populated with human characters. According to Angus Fletcher (2012), the two possibilities of narrative agency in allegories are personifications of abstract ideas and real historical figures. In the two films I propose to analyze here (Caravaggio, 1986, and Edward II, 1991), the protagonists belong to the latter category. As in all allegories, their psychological depth is sacrificed in favour of gesture and iconography. They serve a higher purpose than that of being either heroes or villains. Plus, they inhabit a theatrical world.

As a matter of fact, the films are structured in tableaux, instead of scenes. Therefore, the narrative segments are not in direct temporal or spatial connection

1 In some cases, his use of celebratory camp style further denaturalizes his films. 
to one another and the action is largely metaphorical. In general, an allegory is an opus with two simultaneous meanings: a metaphorical sense is inscribed underneath a more literal one which is directly connected with the actions of the characters and the events of the plot (Xavier 1999). In Jarman's case, the opposite is also true: the abstraction of the whole narrative design is reinforced when we realize that the tableaux may depict past, present or future events in relation to the fabula, and that, furthermore, they may also convey fantasies (usually of a sexual nature), nightmares, lurid dreams, memories and other truly Jungian psychological material of which Jarman was so fond. According to Joel Fineman (1981), the structural success of an allegory is dependent upon the articulation of time and space within its own confines as [physical] text. ${ }^{2}$ Moreover, an allegory appeals to the desire of the spectator in two different but concurrent ways. On the one hand, an allegorical text needs to be unclear so as to trigger a cognitive activity of spectatorial decoding that keeps the interest awake and assures the understanding of the underlying encrypted message (Fletcher 2012). ${ }^{3}$ On the other hand, the desire of interpretation is guaranteed by the running metaphor, since an allegory is really a string of metaphors contributing to the same objective: the transmission of an idea (Fineman 1981, 45).

Besides the overall fragmentary style and scattered narrative, Jarman also used textured images in what Michael O'Pray $(1996,65)$ considers to be an obvious link to his painterly activity. In Caravaggio (1986), which is a straightforward allegory of creation and where the tableaux contain actual tableaux vivants, this is most obvious. "For Jarman, the artist was always identified with this kind of visionary whose magic was equivalent to the procedures of art itself. Art was alchemy" (O’Pray 1996, 69). However, the same can be noted in Edward II, where the art world gives way to an eminently political universe. Edward II is portrayed, by Jarman, as an art enthusiast and the backstage of politics is conveyed as a web of machinations for the benefit of a public: the lords and the nation at large. The king is no less involved in a dialectical relationship with spectators than the painter Caravaggio; he is no less on display and his deeds are no less under scrutiny than his more artistic counterpart's. This is why I prefer to

2 "The text presents us with a self-contained structure of relations. In which elements are manipulated as in a game and that therefore there is neither need nor reason to adduce any extraliterary explanation or justification at all for the particular arrangements that the structurality of the texts allow us to observe" (Fineman 1981, 40).

3 "Enigma, and not always decipherable enigma, appears to be allegory's most cherished function [...]. Since the basic symbolism is highly articulated, he can increase the enigma with even private obscurities, while the allegory as a whole will not thereby disintegrate into nonsense" (Fletcher 2012, 72). 
designate both films as "allegories of spectacle." I contend that by approaching such subjects in a multilayered and multifaceted artistic form, Jarman is stressing both the inner and the outer spectacle in his films (intra and extradiegetic); he is formulating a theory of cinema as a film body through the body of the film which represents its characters in a very corporeal way.

\section{The Body as a Textured Substance}

Both Caravaggio and Edward II are strongly embodied allegories in that they cause the spectator to think upon and make meaning of the diegetic world perceived on screen, but do so along doubly corporeal lines that involve the spectator himself/ herself. All films trigger our spectatorial "carnal thoughts," as Vivian Sobchack calls them (2004). We think and feel with our body, and all of its five senses and proprioceptive abilities, adhering to the films' figurative dimension (their narrative and characters) through a mimetic sympathy that involves as much conscious attention as it does bodily tension (Sobchack 2004, 76). This way the spectator feels his/her body more, reacting in kind to what he/she is shown on screen. However, in the case of Caravaggio and Edward II, a third condition is applicable: the corporeality of the people and things perceived on screen is even more sentient, sensual and sensible than usual. According to Sobchak, films which appeal to our sensorium constitute the true essence of cinema. In the two aforementioned films this is partially achieved through the use of the diegetic bodies, thus reinforcing our spectatorial "sense-ability" during the cinematic experience.

Intradiegetically, Jarman's films are all about the body, mostly the male physique, but not only. Magdalena's corpse in Caravaggio (Tilda Swinton) is made relevant by the way it is transformed into a work of art. Indeed, Lena's drowned body is tended over, her feet washed (in a recurrent gesture of cleansing and purification), her hair brushed by the diegetic painter himself. She looks radiant and not the ugly blown corpse a filthy river might have regurgitated. [Fig. 1.] She is an idea: death, as the ultimate state of perfection. The same can be said of the body of the painter Caravaggio himself (Nigel Terry) when he is associated with the image of Christ, sacrificed in the altar of the philistines' ignorance. His body is poised in abandonment, as he is removed from the cross, in one of the numerous tableaux vivants that permeate this film. [Fig. 2.] He too, is not a sexual figure but a thing of beauty and the transmitter of a message. In fact, on several occasions the characters look directly at the camera, therefore attaining, by default, the cinematic spectator on the other side. The eyes of the characters 
are, simultaneously, imparting the message of the overriding importance of the body and cancelling out their own import in the diegesis, thus ratifying their status as abstractions. [Fig. 6.]

In Caravaggio, the models' bodies and those of the main characters reproduce intradiegetically the texture of art itself. In this perspective, the aforementioned Lena's drowned corpse discloses the director's technique in this film: the body as God's gift to the artist, a material that he/she can shape according to his/her own designs in order to create beauty. In other words, the human body is art in a raw state, totally dependent on the creator's skills to become all that it can be.

Caravaggio's paintings are nowadays renowned for the perfection with which they depict human figures. The diegetic paintings, however, that the character Caravaggio is shown painting in the film are, although still works in progress, far less perfect than the models he is seen using as visual references. [Fig. 3.] The latter not only are for the most part half naked, but they are also framed in a manner that sensually captivates the spectator. The camera does not limit itself to capturing them frontally, as you would expect in a painting (and as the perception of the scene as a tableau vivant actually requires); it also moves laterally behind them, surreptitiously further stressing the corporeality implied. [Fig. 4.] As a matter of fact, this prevents the spectator from seeing the whole diegetic group of people, causing him/her to observe only details of their bodies, which is what the haptic visuality proposed by Laura U. Marks $(2002,3)$ actually does. Metaphorically, the film is depicting our erotic relationship with some cinematic objects, considering that we interchange a dominant voyeuristic look upon the scene with a more tactile and intimate perception of it. [Figs. 3-4.] In the situations where the bodies seen in Caravaggio do not belong to paid models in rigid poses, the male torso is often bare and frequently sweaty as a result of physical activities (sex, fighting). Beside the clearly intended erotic quality, these scenes also emphasize the textural nature of the flesh and human skin in a film about painting. The beads of perspiration which abundantly trickle down the characters' bodies are a sort of dye, the equivalent to the pigment used on the artist's canvas, and they also represent the sort of material surface detail of the film body which Marks calls the skin of the film (2002).

In Caravaggio, the establishing shots are banished altogether: the tableaux either start with a corporeal detail (such as the feet of the young Caravaggio being washed clean by the cardinal Del Monte) or with several close shots unrelated to the surroundings. Indeed, the film itself opens with such a shot: a close up of the old Caravaggio's ailing and worn face. The scars on his cheeks look like tears 
that drip down some Christ image on an altar. The parallelism between religion and art is a motif of the entire film as befits an allegory of creation. Because Caravaggio is explicitly a film about art, it cannot be formally minimalist from beginning to end. The richness of painting calls for a variety of wardrobes and props, as well as sets that are not entirely devoid of dressing. Jarman opts for some semblance of the real, even when the set is, occasionally, stripped of many of its elements. However, one or two exceptions can be observed. For instance, the tavern in which Caravaggio meets Ranuccio (Sean Bean) is a bare greyish cubicle with some men sitting on a few tables. No other decoration is needed here - unlike the scenes that take place in Caravaggio's painting studio - because this is not a metaphor for life and art, and does not contain a representation of a body (an artwork) being inscribed within another (the canvas/the film). [Figs. 7-8.]

However, in order to acquire the status of art, all creations need spectators. In Caravaggio, permanent onlookers accomplish this task. Whenever Caravaggio paints, someone watches: Lena sees him painting Ranuccio; Del Monte observes the painting of a composite canvas; the painter himself contemplates his own painting; and there is, of course, the ever present Jerusaleme. On a basic level, this symbolizes the adoration that all sacred figures and things are prone to, which is ironical since the historical Caravaggio was, in fact, a wild man and led a wanton life. Nevertheless, Michel Foucault, in an article about Velázquez's Las Meninas (1966), pointed to a more complex level of spectatorship whereby the gaze of the characters (the figures) depicted not only calls our attention to the offscreen space of the diegetic situation, but also makes us, onlookers of the artwork feel watched ourselves.

In Edward II, an openly gay opus about a homosexual monarch, the male body is not so undressed and not so textural with sweat or other fluids (such as blood), even though the first scene presents, unabashedly, a male couple of sailors having sex on a bed. In Edward II, the body that matters the most is the political body, i.e. the realm, not the physical body as raw material for the artist. Still, both things cannot be entirely separated and the body remains the key. For instance, the king's lover and favourite, Piers Gaveston (Andrew Tiernan), prances provocatively on the throne in the nude. [Fig. 9.] His bareness, framed in a manner as not to expose his sexual organs, reveals him as a carnal object, but more importantly, as a base creature (here he crouches and clicks his tongue like an animal; later on, after having been forcibly exiled, he howls under heavy rain like a beast). His pose is symbolic of his status in the realm: a predator unbecoming the high society he has entered as favourite of the king. 
In Edward II, the textural pattern has mostly been applied to the sets, stripped to their minimum significant objects: a bow and an arrow to portray a shooting gallery; a table to indicate a dining room or an office; a bed to signify a bedroom; the throne to represent the state room; and so on. It is up to the human figures that inhabit these spaces to make them credible as this or that and to elevate the sets out of their minimalism. Given this improbable and abstract geography, in many scenes it is not even possible to know for certain whether the action is diegetically taking place indoors or outdoors, as all the film was shot in studio. [Fig. 10.] The ceilings are never seen, the doors are simply large openings, the windows are virtually inexistent and the walls and floors are rugged as badly applied plaster (painted in a very dark shade). The space is as empty and abstract as it can be, the major signifiers being the bodies that inhabit it. These acquire an added spatial importance as set dressing, helping to flesh out the tableaux. Concomitantly, their own corporeality is reinforced as on par with the ruggedness of the walls.

\section{Cinematic Body as Spectacle}

The intradiegetic textures - the bodies on screen - always draw our attention to the texture of the cinematic materials as such, the film as body. In general, Vivian Sobchack claims that each film is an expressive entity that can be perceived by the spectator in its literal (or material) dimension, regardless of the nature of the images seen and the sounds heard. The bodies of the characters are inscribed in the body of the film, but the film's body itself is what triggers "our primary engagement [...] with the senses and sensibility of materiality itself" $(2004,65)$. Therefore, in our perception, the film's cinematic texture can be said to precede the film's diegetic textures. According to Laura U. Marks $(2002,8)$, if our look merely scrutinizes the surface of the film, instead of plunging into its depths (where the diegetic universe is situated), we discern texture rather than form. This corresponds to a haptic caress which, in turn, brings about an added sensuality to our film viewing activity. Sobchack (2004) argues for a reciprocal corporeality: the film diegesis (the metaphorical) and the film as matter (the literal) are intertwined in our appreciation of them. ${ }^{4}$ Marks contends that the spectatorial involvement with the film is never psychological, always sensible; however Sobchack claims that the brain is also part of the body, therefore there is no unembodied perceptive

$4 \quad$ For all purposes, according to this author, there are three levels of reversibility in the cinematic experience: the bodies on-screen, the bodies off-screen (i.e. the spectator) and the screen as a body (i.e. the film) (Sobchack 2004, 67). 
activity in cinema viewing $(2004,73)$. Without this important predication the allegories would not be compatible with the inter-artistic embodiment I strongly advocate in this article.

As it is, the discourse on cinema (as art and medium) transmitted by Caravaggio and Edward II is reinforced. These films depict, both in their story and their tissue, the question of the intrinsically corporeal nature of cinema. As a result, the human bodies of the characters, through the films' respective bodies, point yet to another body: Jarman's filmic oeuvre as an intermedial approach to the Seventh Art.

Caravaggio's main credits reveal a brush painting a canvas black, over and over again. We hear the sound of the large brush touching the canvas (as we do later on, in several tableaux where the character Caravaggio is seen painting). The production of the pigments by the mute servant Jerusaleme follows the same auditory pattern. We hear the powders being ground in the mortar and spread out with a knife on a stone. The film presents us with the tools of the intradiegetic art in question (painting) as itself is being laid out for us as Jarman's piece (cinema). The brush, the canvas and the pigments metonymically represent painting as an activity. [Fig. 5.] However, the physical bodies of the people represented and the intensification of the spectator's senses through the pictorial and aural textures connoted with Caravaggio's profession (which allow us to be touched by the film and involved in a visual atmosphere) are what actually transform painting into art. Caravaggio is an allegory of art as requiring a commitment and sacrifices beyond imagination. This is also why the film is punctuated by a lyrical inner voice formed by all Caravaggio's thoughts and remembrances. He transcends his low life beginnings, base human sexual inclinations and violent temperament through the life of the spirit. His body of work (indeed his oeuvre) is the materialization of his inner poet self; all the above mentioned visual and auditory textures only reinforce what the young Caravaggio mentioned himself: that he was an object of art ("oggeto d'arte"), as a male prostitute in his younger years, as well as a major artist, in his later ones.

Admittedly, the narrative condensation, so common in allegories, is here taken to artistic extremes. In Caravaggio, the tableaux are presented out of chronological order (of events). The film starts with the inner thoughts (voice-over) of a dying Caravaggio. As he lies in bed, half-conscious, his remembrances and fantasies are given free rein; it is only through his mind that he continues to exist as a creator. His body is motionless, but he acts as a narrator of the events that he represents, in a psychic patina more lyrical than the actual truth. His dialogue in the flashback scenes he musters is not as poetic, neither is it so full of free associations as the 
text he intones in his dying oratory. The nature of his invocation is uncertain, contributing to make time itself unreliable and baffling. As he recites his thoughts, the sounds of his surrounding reality impose themselves on us.

Very near the beginning of the film, the inner voice of the dying character Caravaggio links three different life periods in only one memory time: we watch a scene that illustrates how Jerusaleme came to be part of the painter's life, as a mute and inept peasant boy sold by his own family; a tableau where Jersusaleme is already grown up, lying next to a goat, a symbolic representation of the shepherd he was meant to be and never was; finally, a film segment where Caravaggio is tended upon by Jerusaleme, who acts like a pet who loves his master. All the while, Caravaggio is talking about his lost love, a boy by the name of Pasqualone, who has nothing to do with what we are watching. The uncertain nature of time, already an intrinsic part of all allegories, is thus made more uncertain by the use of the voice-over. Further down the film, these ruminations of a feverish mind tend to mix past and present, reality and imagination, therefore stressing the illusory nature of art in general and Jarman's film, in particular. Ironically, Caravaggio's self-questioning remark - "All art is against lived experience. How can you compare flesh and blood with oil and ground pigment?" - is contradicted by the film itself through the sensual use of its corporeality. Indeed, the pigments are framed, more than once, in extreme close up, and human blood, including the artist's (when he is wounded during a brawl with knives), is seen on several occasions. Art is no less corporeal than the lived body of humanity.

In Caravaggio, time is even made more obscure by the recurrent darkness of the image. The chiaroscuro lighting is a direct manifestation of the painter's own technique of tenebrism (a mixture of naturalism with a theatrical propensity) and, therefore, engulfs the spectator in the world of the paintings, making the viewer part of the picture viewed, in more senses than one. In fact, the spectator feels himself/herself both part of Caravaggio's canvases and Jarman's film. When, occasionally, some character looks directly at the camera, as do Lena and Jerusaleme, we feel looked upon, not only as film spectators but also as part of a painting, which reinforces the spectacular nature of art. Indeed, the young painter Caravaggio (Dexter Fletcher) is fully aware of the necessary existence of an audience: "I raise this fragile glass and drink to you, my audience". This is the ultimate manifestation of the apparatus in this film. However, the demystification of reality also takes place intradiegetically. [Fig. 7-8.] In one particular instance, the adult Caravaggio watches a street fight between Ranuccio and one of his own friends, beaten to a pulp. The painter is framed in close-up, looking on, 
mesmerized by the bloody spectacle, which the film viewer has the opportunity to watch as a metaphorical projection of silhouettes on a white wall. Similarly, the spectator observes all along the film the painter's fight with his own art through the de-formation of matter on a canvas.

In Edward II, the signs of power are the most important corporeal elements: the throne, the sword, the crown, several types of arms, different uniforms. These are the allegorical emblems that relate to a common destiny and the idea of nation/realm. The film is a discourse on the corrupting nature of power and the prejudices of the majority borne upon different individuals on the grounds of the so-called greater good, but the notion of spectacle is very much present. All political activities imply a measure of putting on a show, as queen Isabella (Tilda Swinton) clearly demonstrates when, taking up arms against her husband, king Edward, she resorts to the media for popularity and validation of an unlawful act (the deposition of a monarch). Edward II himself (Steven Waddington), seeking support for his cause outside the nobility, turns to the people (portrayed as queer activists). Thus, a cry for help is turned into a public demonstration complete with slogans, posters and cameras taking snapshots.

Art is not unrelated to this showmanship. Indeed, very early in the film Gaveston says of Edward: "Music and poetry are his delight. / Sweet speeches, comedies, pleasing shows." The prince is here described as someone who has an artistic propensity and, indeed, several spectacles are seen taking place at court: a man with a python and a golden laurel crown shows off his muscles (which can also be interpreted as an imaginary action); a poet recites an Italian piece in a session attended only by the king and Gaveston (and which takes place in a room with several seats facing the orator). More importantly, it is the intermedial nature of some other spectacles in which Edward himself takes part that calls attention to the analogy intended by Jarman: (a) two men dancing a modern ballet that emulates Edward and Gaveston's relationship (the crosscutting between the dance, which ends in a kiss, parallels Edward kissing Gaveston on the throne); (b) a blonde woman (Annie Lennox) sings a Cole Porter song ("Every time we say goodbye I die a little") involved in a slightly artificial mist while Edward and Gaveston dance alone in a large room lighted by a strong theatrical follow spot (the pair and the singer are all in the same imaginary space and the men actually look at her in the end) [Figs. 11-12]; (c) a female string quartet brought together by Edward to celebrate Gaveston's return from exile (the classical music turns into something lighter as the two men dance once more, this time in a clownish tango mockery, again illuminated by follow spots). 
Music is to the political allegory of Edward II what painting is to the authorial allegory of Caravaggio. Both art media are used to reinforce a significance that is intrinsically cinematic and that takes place at the surface of the film. As I continue to develop the spectacular nature of Edward II, I will refer to many intentional examples of "pro-haptic properties" (Marks 2002), which are also a manifestation of the cinematic apparatus per se and a disclosure of the whole narrative as artifice.

In Edward II, colour is important, but it is almost entirely dependent on the lighting, which is pointed directly at the characters through the use of key lights placed higher or lower than the human eyes, giving the tableaux a strong theatrical impression. The characters seem to be always on a stage, as public figures usually are. Therefore, the bareness of the sets not only stresses the allegory, but also reinforces the spectacular nature of the film as an ode to spectacle, far beyond the political world it depicts. While part of the image is deliberately kept in darkness, making the background often unnoticeable, the rest is lighted by strong projectors, resulting in a very marked contrast. Indeed, Edward II is fraught with flares, most of them induced by diegetic flashlights. The use of strong key lights strategically placed also creates huge shadows, reminiscent of German Expressionism, and the appearance of silhouettes points to the Oriental shadow theatres that constitute the archaeological origins of cinema. [Fig. 14.] Blue and red filtered shots transform characters and spaces in one-dimensional images endowed with strong symbolic modulations. Thus is the lighting made evident as an artistic praxis and a tool with which to work the texture of the film, calling to attention its artificial cinematic nature.

In Edward II, the disclosure of the apparatus points to a spatial duality: the "there" of the screen, where the film evolves; and the "here" of the audience, where the film is watched (and, therefore, validated as such). In phenomenological terms, this is evidence of corporeal reversibility. The off-screen space is the locus of the viewer and that is why, in this film, the spectator is also of the utmost importance. In fact, early cinema rose out of vaudeville and its sensorial display, as did the musical comedy. Significantly, a twofold act of communication is required for such entertainment convention to work: the film and the audience must interact with each other. ${ }^{5}$ At a sensorial level that is exactly what Jarman means to accomplish.

Edward II is filled with shot/reverse shot framings, constantly opposing (and, simultaneously, joining) the two sides of space. For instance, when Gaveston is

$5 \quad$ In her canonical book about musical, Jane Feuer (1982) states that in no other type of musical was the communication with the audience so emulated as in the backstage musical, which had intradiegetical spectators intercut with the performers acting on stage. 
exiled, by order of Edward, he is symbolically escorted out of the country by the clergy. First we see him with his back to the camera, walking past the priests who spit on him from either side of the road; next we see him being spat upon as he walks towards the camera, face to us, until he reaches the end of the road. By the use of the reverse shot the spectator is partly transformed into spectacle and viceversa. This has obvious implications in how the viewers of Jarman's film engage in what they are watching. They are attracted as the audience of a musical film, of which Edward II obviously carries the marks, by the use of their sensations and emotions. However, by osmosis, they also feel spat upon, which is not a physically comfortable feeling.

\section{Immersive Allegorical Intermediality}

The allegory employed by Jarman is capable of incorporating emblems, endowed with a very strict pre-existing meaning, as well as symbols, where all the free association of ideas is concentrated. In corporeal terms, the hybridization of arts, typical of intermediality, is responsible for what can be seen as a paradox: a sparse and abstract diegetic universe coexists with a rich and all-encompassing viewer immersion.

Caravaggio and Edward II are able to combine the bareness of the sets with the opulence of the texture, in part because the films are enriched by other media and other arts. The deliberate mixture of times and realities turns each and every single gesture and creative action depicted in the films into a sign to be decoded by the spectator. Thus begins the plunge in the film, whose narrative labyrinth the viewer finds himself/herself inescapably immersed in. All allegories are enigmas that entail a necessary work of spectatorial reconstruction. In Jarman's two films analysed here, the use of other art forms is made part of that enigma. For instance, in Edward II a boys' angelical choir constitutes the background music to a violent sodomy act, which is only recognized as Edward's fearful imagination after the deed is supposedly done (the slow motion is already a hint, though).

This first level of immersion is part of the symbolic network of both films. The agonizing painter, in Caravaggio, alludes in voice-over to a close escape from death by drowning, presumably after a shipwreck (whose occurrence we never see confirmed). His younger incarnation mentions painting himself as Bacchus and, surely enough, the film presents us with a short editing flash which reproduces the celebrated canvas, in the form of a tableau vivant, starring the actor Dexter Fletcher, who plays the title role in Caravaggio's youthful years. 
Later, the two motifs come together in an ironic twist, typical of Jarman, when the nobleman who behaves as an art critic, harsh on Caravaggio's work, dies in the bathtub with the looks and the pose of Jacques-Louis David's The Death of Marat (1793). In Edward II, the protagonist is often seen in an undefined space that seems to exist underground and which is depicted as a dark place made of metal and rivets, where a furnace shines and fire glitters. It could symbolize hell in western cultural imagery, were it not for the water it contains. This water can be construed, on several occasions during the film, as: (a) an underground spring; (b) a sewer; (c) a pond. Beautiful reflections emanate from it as Edward rests close to the water and speaks of his dual nature, made up of himself and Gaveston. At this point, the image almost reproduces the pictorial Narcissus as painted by the historical Caravaggio (1594-1596).

Inasmuch as allegory is very conceptual and characterized by a high degree of abstraction, there seems to be no room for sensorial immersion. However, both films harbour a second level of meaning and matter through which Jarman proves this to be a preconceived idea. Both films transpire with eroticism and are illuminated by an attractive power that keeps the spectators enwrapped in the diegetic world of the characters and the ritualistic atmosphere of the whole picture. The above puns are intended, for as Sobchack mentions, the spectator is a "cinesthetic subject" endowed with an embodied vision "in-formed" by the knowledge imparted through the other senses (2004, 70-71). Jarman makes excellent use of our intrinsic "synaesthetic perception" (2004, 70). In fact, a text full of music sculptured with light, enhanced with colour and human figures, either tri- or bi-dimensional, is never an empty text: it has volume, shape, depth, colour, etc. and can be apprehended as such. In other words, these films create a coenasthesia capable of making the spectator inhabit the world on the screen and experience more fully the contact with the screen as a world. The space is transformed into a place, as abstract as it is alluring.

Caravaggio and Edward II exhibit a corporeality that magnifies art, calling to attention the artistry as enriched matter, in turn causing the enhancement of our sensual being. In these cases, the spectator, Sobchack argues, goes through an "as if" situation where he/she experiences general and diffuse sensations (i.e. not specifically directed at anything) in which his/her body is touched both in a literal and figural sense, that is, directly (in itself) and indirectly (through the bodies of the characters on screen). In conclusion, our film viewing "skin" opens us to "fabrics and their textures" (Sobchack 2004, 78-79). Like an unsuspicious fly, the spectator falls into the creator's web of art through art itself. 


\section{References}

Feuer, Jane. 1982. The Hollywood Musical. London and Basingstoke: BFI/ Macmillan Press.

Fineman, Joel. 1981. The Structure of Allegorical Desire. In Allegory and Representation, ed. Stephen J. Greenblatt, 26-60. Baltimore and London: The Johns Hopkins University Press.

Fletcher, Angus. 2012. Allegory: The Theory of a Symbolic Mode. Princeton and Oxford: Princeton University Press.

Foucault, Michel. 1998. Les mots et les choses. [Words and Things], Paris: Gallimard.

Julien, Isaac. 2008. Derek. BFI.

Marks, Laura U. 2002. Touch: Sensuous Theory and Multisensory Media. Minneapolis and London: University of Minnesota Press.

O'Pray, Michael. 1996. Derek Jarman: The Art of Films/Films of Art. In Derek Jarman: A Portrait, ed. Roger Wollen, 65-75. London: Thames and Hudson.

Owens, Craig. 1980. The Allegorical Impulse: Toward a Theory of Postmodernism. October vol. 12: 67-86.

Sobchack, Vivian. 2004. Carnal Thoughts: Embodiment and Moving Image Culture. Berkeley, Los Angeles and London: University of California Press.

Watson, Gray. 1996. An Archeology of Soul. In Derek Jarman: A Portrait, ed. Roger Wollen, 33-48. London: Thames and Hudson.

Wollen, Roger. 1996. Facets of Derek Jarman. In Derek Jarman: A Portrait, ed. Roger Wollen, 15-31. London: Thames and Hudson.

Xavier, Ismail. 2004 [1999]. A alegoria histórica. [Historical Allegory]. In Teoria Contemporânea do Cinema, vol. I - Pós-estruturalismo e filosofia analítica [Contemporary Cinema Theory, vol. I - Post-Structuralism and Analytic Philosophy], ed. Fernão Pessoa Ramos, 339-379. São Paulo: Editora Senac. 


\section{List of Figures}

Figures 1-8. Caravaggio (1986):

Corpses transformed into works of art: death as the ultimate state of perfection.
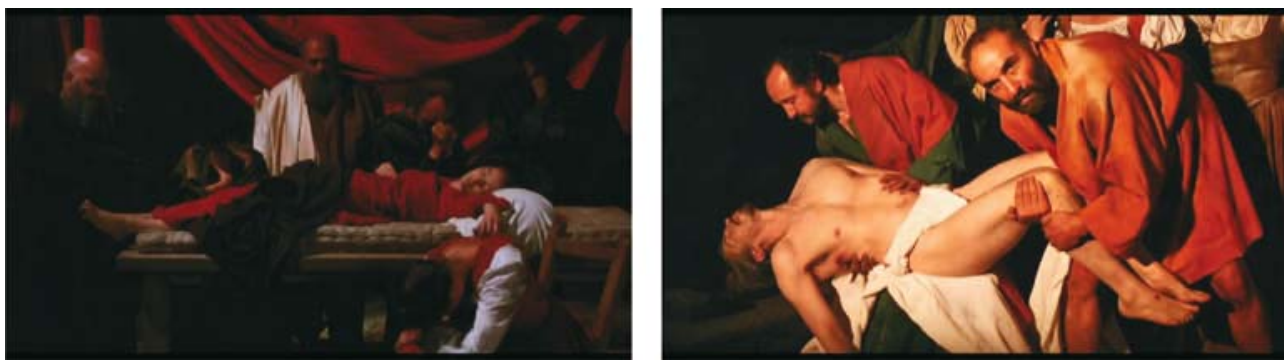

Captivating details that enhance voyeurism.
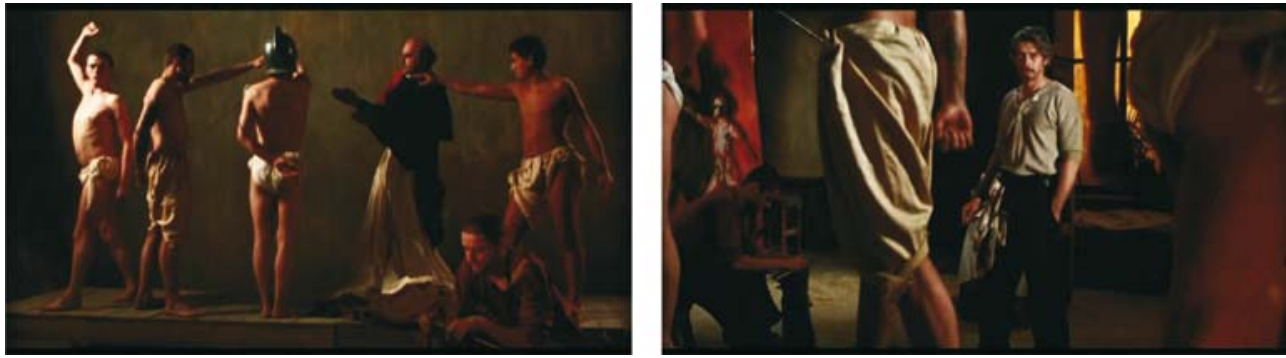

The textures of the medium. The spectator in the film as part of the artwork.
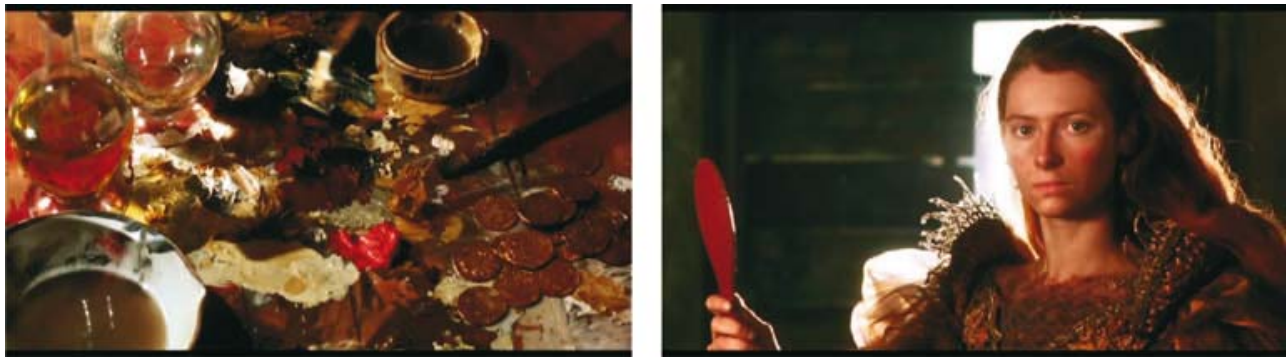

Strong pictorial impression: the surface (screen) and the apparatus.
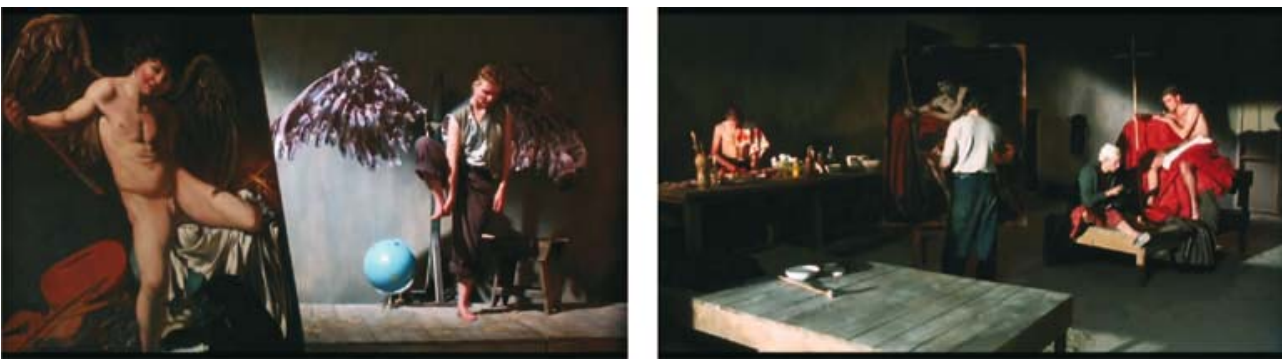
Figures 9-14. Edward II (1991):

Political body $=$ physical body. Empty and abstract space: human bodies as major signifiers.
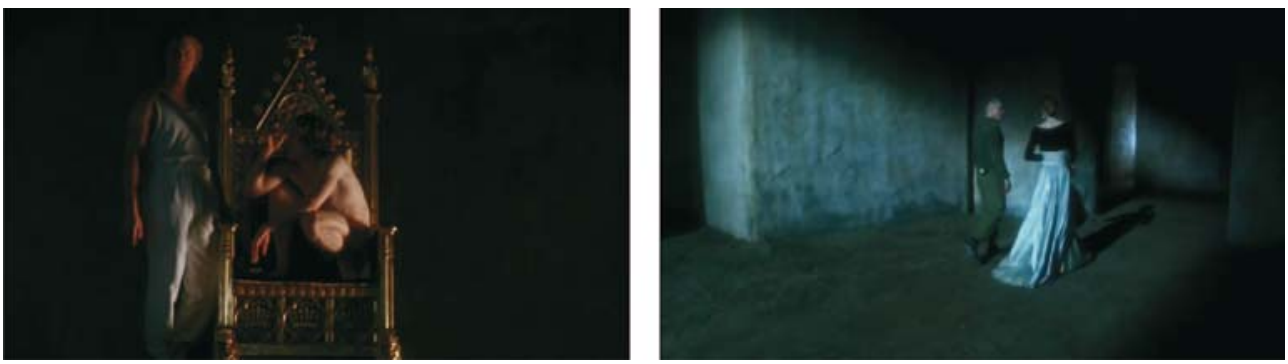

Statesmen are also showmen.
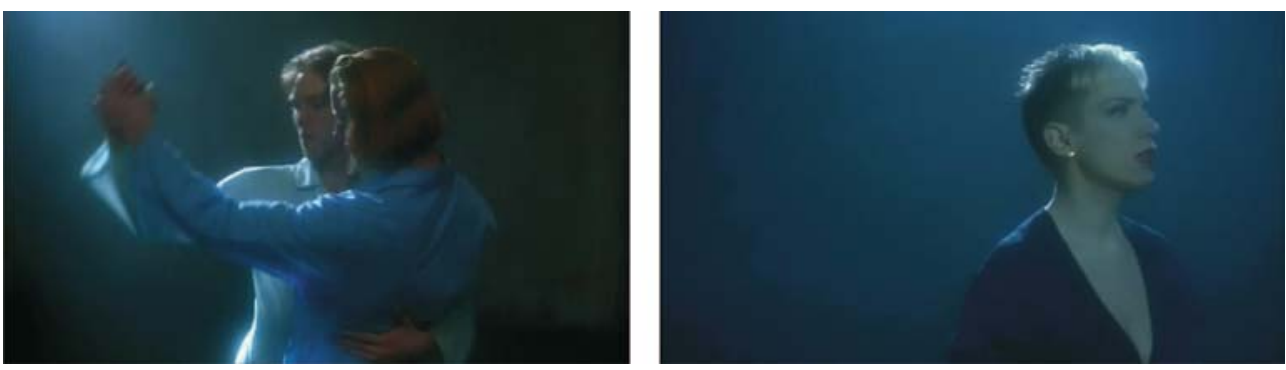

Strong theatrical impression: characters "on stage."
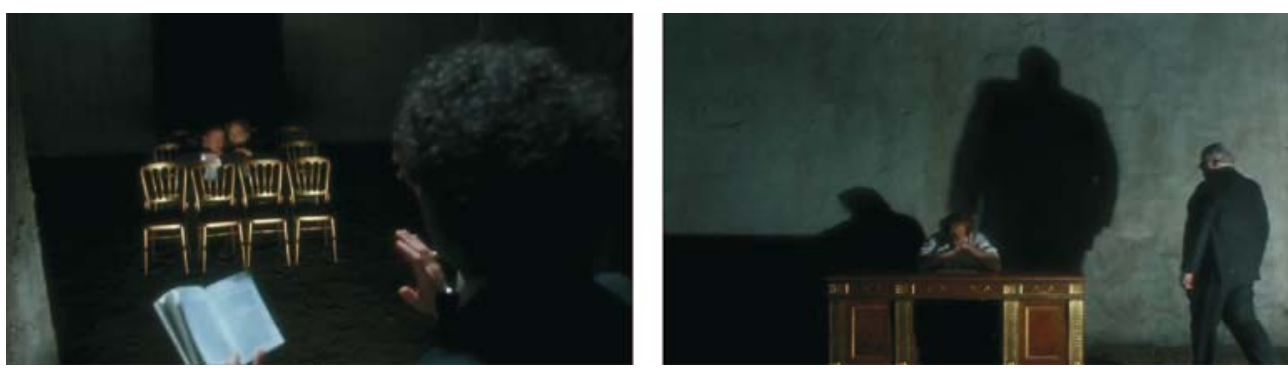